\title{
Monograf
}

\section{STATUS DAN MITIGASI DINI SERANGAN PENYAKIT PINUS di JAWA TIMUR}

\section{Menuju Agroforestri Sehat Berbasis Pinus}

\section{Sutarman}

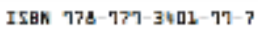

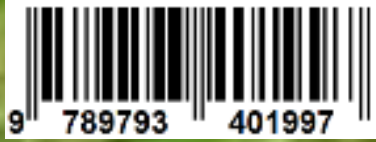




\title{
Monograf
}

\section{STATUS DAN MITIGASI DINI SERANGAN PENYAKIT PINUS di JAWA TIMUR}

Menuju Agroforestri Sehat Berbasis Pinus

\author{
Oleh \\ Sutarman
}

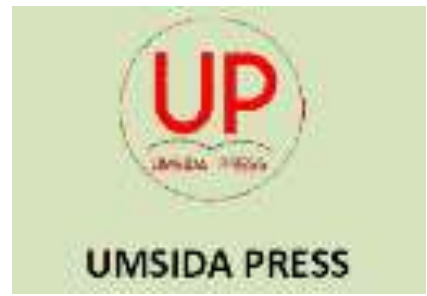

Diterbitkan oleh UMSIDA PRESS

Jl. Mojopahit 666 B Sidoarjo

ISBN: $x x x-x x x-x x x x-x x-x$

Copyright (C2018

Sutarman

All rights reserved

Hak cipta dilindungi undang-undang.

Dilarang memperbanyak atau memindahkan sebagian atau seluruh isi buku ini ke dalam bentuk apapun, secara elektronis, maupun mekanis, termasuk fotokopi, merekam, atau dengan teknik perekaman lainnya, tanpa izin tertulis dari penerbit.

[Berdasarkan UU No. 19 Tahun 2000 tentang Hak Cipta Bab XII Ketentuan Pidana, Pasal 27, Ayat (1), (2), dan (6). 


\section{Monograf}

Status dan Mitigasi Dini Serangan Penyakit Pinus di Jawa Timur

Menuju Agroforestri Sehat Berbasis Pinus

Penyusun

Sutarman

Dosen Program Studi Agroteknologi

Fakultas Pertanian, Universitas Muhammadiyah Sidoarjo

Editor ahli

Prof. Dr. Ir. Siti Rasminah Ch. Sy., MS

Editor

Dyah Satiti, MT

Penerbit

\section{UMSIDA PRESS}

P3I Universitas Muhammadiyah Sidoarjo

Kampus 1 Universitas Muhamamdiyah Sidoarjo

Jl. Mojopahit 666 B Sidoarjo, Jawa Timur, Indonesia

Telp. +62318945444

Fax +62 318949333

https://p3i.umsida.ac.id 


\section{KATA PENGANTAR}

Puji syukur kehadirat Allah SWT atas tersusunnya monograf yang merupakan salah satu luaran penelitian yang dimulai sejak 2014/2015 hingga akhir 2017 sesuai kompetensi penyusun di bidang kesehatan dan penyakit tanaman.

Buku ini disusun berdasarkan hasil penelitian observasi dan eksperimental serta kajian literatur yang bersumber pada berbagai artikel jurnal nasional dan Internasional relevan terkait.

Penyiapan bioteknologi bagi agroforestri berbasis model tumpangsari tanaman muda pinus dan hortikultur yang memiliki fungis mitigasi serangan penyakit oleh soil borne pathogen di masa depan adalah merupakan nilai kebaruan dalam penelitian ini .

Pada kesempatan ini penulis menyampaikan terima kasih kepada: Rektor Universitas Muhammadiyah Sidoarjo (UMSIDA), Dekan Fakultas Pertanian, Kepala LPPM, serta Kepala Laboratorium Agrokompleks UMSIDA atas dukungan moril dan fasilitas yang disediakan bagi kelancaran penelitian dan penyusunan buku ini.

Semoga karya ilmiah ini bermanfaat.

Sidoarjo, Mei 2018

Penyusun 
Halaman

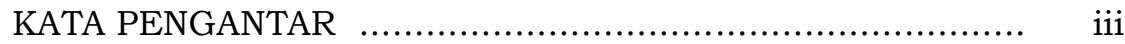

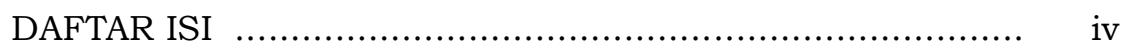

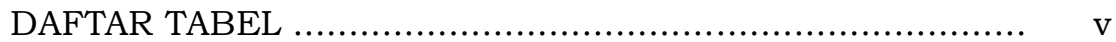

DAFTAR GAMBAR ................................................ vi

BAB 1. PENDAHULUAN .............................................. 1

BAB 2. TINJAUAN PENYAKIT TANAMAN ....................... 7

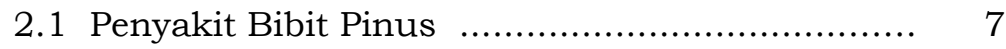

2.2 Epidemiologi Penyakit dan Inang Alternatif ....... 9

BAB 3. PENGENDALIAN HAYATI …............................. 13

3.1 Tinjauan Pengendalian Penyakit Pinus ........... 13

3.2 Trichoderma Sebagai Fungi Efektif ............... 16

BAB 4. METODE PENELITIAN …................................ 18

4.1 Tempat dan Waktu Penelitian ..................... 18

4.2 Gejala Serangan Penyakit ........................... 18

4.3 Isoalsi dan Pengamatan Patogen .................. 19

4.4 Profil Serangan Penyakit Pinus .................... 20

4.4.1 Status Serangan hawar daun .............. 21

4.4.2 Status Serangan berdasarkan ketinggian tempat ...................................... 24

4.4.3 Peta Serangan Hawar Daun ................ 24

4.5 Isolasi Trichoderma ................................. 24

4.6 Uji Daya Antagonistik Trichoderma .............. 24

BAB 5. HASIL DAN PEMBAHASAN ................................. 29

5.1 Gejala Serangan Penyakit ........................ 29

5.1.1 Gejala hawar daun pinus ................... 29

5.1.2 Gejala Serangan damping off .............. 33

5.2 Hasil Isoalsi Patogen ................................. 34

5.2.1 Patogen hawar daun pinus ................. 34

5.2.2 Patogen damping off ........................ 36

5.3 Profil Serangan Penyakit Pinus .................... 37

5.3.1 Status Serangan hawar daun ............. 39

5.3.2 Status Serangan berdasarkan ketinggian 
tempat

5.3.3 Peta Serangan Hawar Daun ................. 47

5.4 Trichoderma Aensia Hayati Potensial ............. 50

5.5 Uji Daya Antagonistik Trichoderma .............. 51

5.5 .1 Uji in vitro ................................ 51

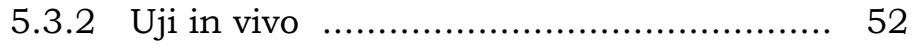

5.6 Mitigasi Dini Serangan Penyakit ................. 55

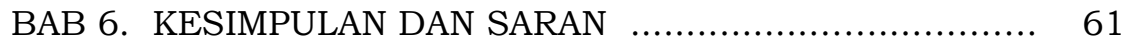

6.1 Kesimpulan .......................................... 61

6.2 Saran ................................................... 62

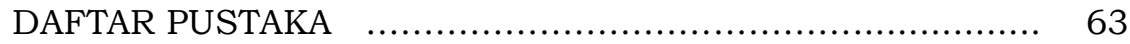




\section{DAFTAR TABEL}

Halaman

1. Skor derajat serangan berdasarkan kriteria gejala hawar daun bibit pinus

2. Skor derajat serangan dan kategori kesehatan tegakan berdasarkan kriteria gejala hawar daun tegakan pinus

3. Status serangan penyakit hawar daun pada tegakan tegakan

4. Pengamatan rerata intensitas gejala serangan penyakit bibit pada beberapa umur

5. Deskripsi patogen damping off pada pinus

6. Status penyakit hawar daun pinus di wilayah pengelolaan hutan KPH Pasuruan dan KPH Malang (kawasan utama hutan pinus) Perum Perhutani Unit Jawa Timur

7. Hasil pengamatan status serangan penyakit bergejala hawar daun pada tanaman/tegakan $P$. merkusii pada representasi berbagai ketinggian tempat di KPH Pasuruan ................

8. Hasil pengamatan status serangan penyakit 43 bergejala hawar daun pada tanaman/tegakan $P$. merkusii pada representasi berbagai ketinggian tempat di KPH Malang

9. Hasil pengamatan status serangan penyakit bergejala hawar daun pada tanaman/tegakan P. merkusii pada representasi berbagai ketinggian tempat

10. Peta serangan hawar daun pinus pada wilayah representasi kawasan hutan pinus di Jawa Timur 


\section{DAFTAR TABEL}

Halaman

11. Rerata persentase kejadian penyakit hawar daun bibit $P$. merkusii sebagai respons aplikasi dua isolat Trichoderma sebagai biopestisida dan biofertilizer pada satu bulan setelah inokulasi

12. Rerata persentase kejadian penyakit damping off kecambah $P$. merkusii sebagai respons aplikasi dua isolat Trichoderma di baki perkecambahan pada tiga minggu setelah inokulasi 
1. Rataan mingguan curah hujan rata-rata harian $(\mathrm{mm})$ di area persemaian ..................... 11

2. Rataan mingguan durasi sinar matahari mencapai tajuk (\%) di area persemaian .......... 12

3. Rataan mingguan kelembaban relatif udara rata-rata harian (\%) di persemaian ............... 12

4. Proyeksi tampilan koloni pada uji antagonistik metode dual culture

5. Gejala serangan pada bibit P. merkusii; gejala serangan berat dan kematian bibit (kiri) serta "mosaic" gejala serangan pada bedeng persemaian pinus

6. Representasi gejala serangan hawar daun pada tanaman $P$. merkusii di lapang

7. Tegakan pinus yang menunjuk gejala hawar secara masif

8. Gejala damping off bibit pinus

9. Morfologi, koloni (pada PDA-c), dan miseium (pada tabung rekasi) patogen $P$. theae yang diisolasi dari daun bergejala hawar

10. Koloni dalam cawan petri dan tabung reaksi, serta konidiospora, Trichoderma sp. yang diambil dari Claket, KPH Pasuruan ..............

11. Pertumbuhan daya hambat dua isolat Trichoderma sp. terhadap $P$. theae patogen hawar daun pinus ....................................

12. Bagan alir tahap kegiatan penelitian yang bertujuan merancang strategi mitigasi dan pengendalian hayati dalam agroforestri berbasis pinus 


\section{BAB 1 \\ PENDAHULUAN}

Pinus merkusii merupakan tanaman penting di Indonesia bukan hanya sebagai penghara kebutuhan industri perkayuan dan industri berbasis getah sadapan, tetapi juga berperan dalam fungsi pengendali hidrologis kawasan dan industri ekowisata. Hasil observasi yang dilakukan di berbagai klaster pertanaman pinus di sebagian pulau Jawa menunjukan adanya kesamaan pola serangan hawar daun dan patogen penyebab penyakit yang relatif sama [1].

Status organisme penyebab penyakit hawar daun pinus dalam dua hingga tiga dekade yang lalu sebagai patogen lemah diduga kini sebagai bentuk adaptasi terhadap perubahan iklim berubah secara evolutif menjadi penyebab penyakit berbahaya dengan kisaran wilayah serangan bersifat meluas. Berbagai tindakan silvikultur/agronomis ternyata tidak mampu mencegahnya perkembangan gejala penyakit hawar daun terutama pada bibit P. Mekusii [2].

Top soil dari bawah tegakan pinus yang biasa digunakan sebagai komponen media tanam bibit telah menjadi media bagi penyebaran spora $P$. theae ke tempat persemaian [3]. Di samping itu, kemampuan patogen ini menginfeksi gulma dan tanaman pinus dewasa, serta mampu menginfeksi berbagai jenis dan strata pertumbuhan tanaman $[4,5,6]$, membuat propagul $P$. theae selalu tersedia dan menjadi ancaman yang serius bagi bibit pinus.

Interaksi antara patogen dan pertanaman $P$ merkusii termasuk inang alternatif, serta pengaruh dinamika 
perubahan iklim dapat mempengaruhi dan mendorong virulensi patogen dan peningkatan kerentanan tanaman yang diwujudkan dalam suatu fakta adanya peningkatan intensitas dan luas serangan hawar daun bibit pinus. Berdasarkan karakter patogenesis $P$. theae [7] dan karakter epidemiologinya [3], maka "oubreak" penyakit hawar daun pinus merupakan suatu kenisayaan yang dapat menghancurkan sistem penyiapan permudaan $P$. merkusii, yang berarti merupakan ancaman serius bagi kelangsungan dan kelestarian hutan pinus di Jawa Timur dan sekitarnya pada khususnya serta di hutan pinus lainnya di Indonesia.

Saat ini dalam rangka mewujudkan dan meningkatkan ketahanan pangan, maka intesifikasi budidaya tanaman pertanian tidaklah memadai. Di Indonesia dari 191,09 juta Ha lahan pertanian sebesar 67,2\% adalah lahan kering serta terdapat 12,01 juta hektare tegal atau kebun yang kurang produktif dan 11, 7 juta hektare lahan tidur yang belum dimanfaatkan [8]. Namun demikian ekstensifikasi atau pembukaan lahan bagi pengembangan pertanaman pangan bukan hal yang mudah. Selain dihadapi oleh masalah status lahan juga karena berbagai tantangan dalam usaha pertanian lahan kering di antaranya adalah: kemasaman atau $\mathrm{pH}$ tanah yang rendah, kapasitas tukar kation yang rendah, kekahatan $\mathrm{P}$, cekaman air [9].

Pemanfaatan lahan perkebunan dan lahan hutan yang didominasi oleh pohon dan tegakan untuk pengembangan peranaman pangan adalah dengan mengimplementasikan berbagai variasi teknologi agroforestri. Persoalan yang 
muncul pada sistem agroforestri dengan tanaman pokok memiliki tajuk yang menaungi tanaman di bawahnya adalah intensitas sinar matahari yang rendah. Untuk mengatasi cekaman naungan, maka berbagai penelitian telah yang bertujuan menghasilkan tanaman pangan tahan naungan.

Sistem agroforestri berbasis pinus akan menguntungkan bagi upaya peningkatan produksitivitas lahan jika pertanaman pinus dalam kondisi sehat. Hutan pinus di Jawa Timur berperan penting dalam pengaturan hidrologi kawasan [11] dan menjadi penyangga kehidupan masyarakat baik di bagian hulu maupun hilir. Idealnya produksi tanaman pangan terjaga namun produktivitas pertanaman pinus juga tetap optimal. Pada wilayah yang saat ini merupakan kawasan hutan pinus sudah dimaklumi memiliki manfaat yang sangat besar bagi keajegan: produksi kayu, produksi getah-getahan penghara berbagai industri, penghasil dan penopang industri wisata alam, serta pendukung utama terciptanya sistem hirologis hutan yang menjamin ketersediaan air bagi kehidupan manusia.

Salah satu pengancam kelestarian hutan pinus adalah gangguan patogen penyebab penyakit. Bibit yang gagal diproduksi akan menyebabkan kegagalan penanaman kembali pinus yang ditebang karena sudah melewati umur daur. Tanaman muda dan tegakan pinus yang selalu mendapat tekanan penyakit akan dapat mengancam eksistensi dan kelestarian hutan pinus di Jawa. Bibit dan tanaman pinus yang terinfeksi peyakit juga akan menjadi 
menghasilkan propagul infektif yang dapat menyerang dan merusak tanaman pertanian di dalam sistem agroforestri dan/atau pada tanaman pertanian di sekitar kawasan hutan pinus.

Dengan pertimbangan bahwa dalam 2-3 dasawarsa terakhir telah terjadi fluktuasi iklim yang ekstrim, maka tentunya akan berdampak pada kehidupan organisme termasuk penurunan ketahanan tanaman terhadap cekaman lingkungan dan sebaliknya berdampak pada peningkatan virulensi patogen.

Untuk itu perlu dipelajari secara seksama dampak perubahan iklim terhadap kehidupan organisme. Hawar daun pinus misalnya sebelum tahun 1990-an dianggap patogen minor, tetapi awal 2000-an di Jawa Barat dan Jawa Tengah menimbulkan gagguan berat pada kesehatan bibit tanaman dan menghasilkan propagul infektif ketika menyerang tanaman dewasa atau tegakan [1]. Saat ini perlu dievaluasi status serangan penyakit ini khususnya di Jawa Timur dan lebih spesifik di kawasan utamanya hutan pinus di mana di dalamnya telah dikembangkan sisten agroforestri yang berbasis pada tumpang sari pinus dan tanaman hortikultur strategis.

Di lain pihak, saat ini penggunaan pestisida seringkali tidak efektif mencegah kerusakan dan penyebaran penyakit. Kesadaran yang mulai meningkat di kalangan konsumen sayuran dan produk pangan, maka berbagai upaya untuk mensubtitusi pestisida merupakan tantangan yang memerlukan jawaban sesegera mungkin. 
Pemanfaatan Trichoderma yang diambil dari lahan hutan merupakan salah satu harapan bagi upaya pengembangan agroforestri yang sehat tanpa pestisida kimia. Saat ini banyak penelitian pemanfaatan Trichoderma, namun sebagian terbesar pada ranah komodiats pertanian. Untuk itu perlu lebih ditumbuh-kembangkan penelitian pemanfaatan Trichoderma untuk dapat memberikan sumbangan bagi penciptaan agroforestri yang sehat.

Penelitian pemanfaatan Trichoderma untuk pengendalian damping off pada fase perkecambahan pinus telah terkonfirmasi [12] dan menunjukkan prospek yang menjanjikan pada tahap implementasinya. Sementara itu telah dilakukan pula pengujian potensi fungi Trichoderma yang bersifat soil borne sebagai agen biokontrol dalam ranah air borne agar mampu mengatasi gangguan penyakit busuk lada bukan hanya di dalam tanah dan di pangkal batang tetapi lebih tinggi lagi mendekati tajuk [13]. Trichoderma sp yang berasal dari lahan hutan ternyata juga menunjukkan kemampuannya sebagai agensia pengendali hayati di permukaan daun bibit kakao [14].

Dengan berbagai pertimbangan nilai pentingnya fungi efektif dan potensi ancaman patogen di area hutan pinus, maka sangat diperlukan penelitian komprehensif yang bersifat menguji kinerjanya dalam melindungi kesehatan tanaman pinus sekaligus tanaman hortikultur strategis yang biasa dikembangkan di kawasan hutan pinus. 
Penelitian ini bertujuan untuk memberikan gambaran tentang prospek pengendalian penyakit utama pinus yang meliputi:

a. Mengetahui dan mendeskripsikan gejala penyakit pinus terutama hawar daun dan damping off di kawasan hutan pinus Jawa Timur;

b. Mengetahui dan mendeskripsikan patogen penyakit pinus terutama hawar daun dan damping off di kawasan hutan pinus Jawa Timur;

c. Mengetahui penyebaran penyakit hawar daun bibit dan tajuk tegakan pinus di Jawa Timur;

d. Mengetahui daya hambat Trichoderma yang diisolasi dari area persemaian baik secara in vitro dan in vivo terhadap patogen utama penyakit pinus;

e. Menjelaskan strategi mitigasi dini serangan penyakit pinus di Jawa Timur. 


\section{DAFTAR PUSTAKA}

[1] Sutarman. 2017. The impact controlling of the increasing plant pathogens virulence to prevents environmental degradation, In: In'am A, Latipun, Hiley H, Musa MZ, Bantala DS, \& Batre NM (eds.), Proceedings 4th International Conference the Community Development in ASEAN, 21-23 March 2017, pp. 789-803. Royal Academy of Cambodia, 
Russian Federation Blvd, Pochentong Phnom Penh Cambodia

[2] Sutarman, Achmad, \& Hadi S. 2001. Penyakit hawar daun bibit Pinus merkusii di pesemaian. Agritek 9: 1419-1427

[3] Sutarman, S. Hadi, A. Saefuddin, Achmad, \& A. Suryani. 2004. Epidemiologi hawar daun bibit Pinus merkusii yang disebabkan oleh Pestalotia theae. J. Manajemen Hutan Tropika 10 (1): 43-60

[4] Canon P. 1997. Report on fungi from diseased Acacia samples examined at Institute of Horticultural Development, Knoxfield Victoria. Hlm. 108-113 dalam Proceedings of an International Workshops held at Subanjeriji (South Sumatra); Subanjeriji; 28 April - 3 May 1996. Old KM, See LS, Sharma JK (peny.). Bogor: Cifor Special Publication

[5] Old KM. 1997. Diseases of tropical acacias in Torthern Queensland. Hlm. 1-22 dalam Proceedings of an International Workshop held at Subanjeriji (South Sumatra); Subanjeriji; 28 April - 3 May 1996

[6] Sharma JK \& Florence EJM. 1997. Fungal pathogens as a potential threat to tropical acacias: case study of India. Hlm. 70-107 dalam Proceedings of an International Workshop held at Subanjeriji (South Sumatra); Subanjeriji; 28 April - 3 May 1996. Old KM, See LS, Sharma JK (peny.). Bogor: Cifor Special Publication

[7] Sutarman, S. Hadi, A. Suryani, Achmad, \& A. Saefuddin. 2004. Patogenesis hawar daun bibit Pinus merkusii yang disebabkan oleh Pestalotia theae di pesemaian. J. Hama dan Penyakit Tumbuhan Tropika 4(1): 32-41

[8] Yulida M. 2016. Ini Jurus Kementan dan F AO Agar Lahan Kering Bisa Digarap Petani.https:/ / finance.detik.com/ekonomi-bisnis / 3364375/ini-jurus-kementan -dan-fao-agar-lahan -kering-bisa-digarap-petan. Diakses 2 Mei 2017 
[9] Katadata. 2017. Pemanfaatan 36,8 juta hektare lahan pertanian belum maksimal. http://katadata.co.id/berita/2016/12/07/jokowipemanfaatan -368-juta-hektare-lahan-pertanian -belum-maksimal. Diakses 22 April 2017

[10] Sukarno A., Hardiyanto E.B., Marsoem S.N., \& Na’iem M. 2013. Correlation of drill size defferences on resin production of Pinus merkusii Jungh Et De Vriese. J-PAL 4 (1): 38-42

[11] Pemprov Jawa Timur. 2005. Peraturan Daerah Propinsi Jawa Timur Nomor 6 Tahun 2005 tentang Penertiban dan Pengendalian Hutan Produksi di Propinsi Jawa Timur

[12] Achmad, S. Hadi, EG Sa'id, B. Satiawihardja, MK Kardin, \& Harran S. 1999. The potential use of two species of Trichoderma for the biological control of damping-off on Pinus merkusii. Hal. 103-107 dalam Proceedings of Manila Workshop. RE De la Cruz, M Follosco, K Ishii (peny.). Manila, Philippines BIIOREFOR/IUFRO/SPDC

[13] Ginting C dan Maryono T. 2012. Penurunan keparahan penyakit busuk pangkal batang pada lada akibat aplikasi bahan organic dan Trichoderma harzianum. J. HPT Tropika 12:162-168

[14] Nurudin MJ \& Sutarman. 2014. Potensi Trichoderma sp. sebagai penegndali Phytopthora palmivora penyebab hawar daun bibit kakao. J. Nabatia 11 (1):21-28

[15] Achmad, S Hadi, S Harran, EG Sa'id, B Satiawihardja, \& Kardin MK. 1997. Biochemical Defence Of Pinus merkusii Seedlings Against Damping-Off Pathogens. Hal. 237-240 dalam Proceedings of Brisbane Workshop. J Kikkawa, P Dart, D Doley, K Ishii, D Lamb, K Suzuki (peny.). Brisbane, Australia BIIOREFOR/IUFRO/SPDC

[16] Rahayu, S. 2000. Potensi ektomikoriza dalam menurunkan intensitas penyakit busuk akar dan kering pucuk pada semai Pinus merkusii. Hlm. 147153 dalam Prosiding Hasil Seminar Nasional 
Mikoriza I; Bogor; 15-16 November 1999. Anonim (peny,). Pusat Penelitian dan Pengembangan Hutan. Bogor

[17] Bailey MJ \& Pessa E. 1990. Strain and process for production of polygalacturonase. Enzyme Microb. Technol. 12: 266-271

[18] Huber L \& Gillespie TJ. 1992. Modelling leaf wetness in relation to plant disease epidemiology. Annu. Rev. Phytopathol. 30: 553-577

[19] Abbas HK, Egley GH, \& Paul RN. 1995. Effect of conidia production temperature on germination and infectivity of Alternaria helianthi. Phytopathology 85: 677-682

[20] DeVallavieille-Pope C, Huber L, Leconte M, \& Goyeau H. 1995. Comparative effects of temperature and interrupted wet periods on germination, penetration, and infection of Puccinia recondita f. sp. tritici and $P$. striformis on wheat seedlings. Phytopathology 85: 409-415

[21] Gilles T, Fitt BD dan Jeger MJ. 2001. Effect of environmental factors on development of Pyrenopeziza brassicae (light leaf spot) apothecia on oilseed rape debris. Phytopathology 91: 392-398

[22] Agrios GN. 1997. Plant pathology. Edisi ke-4. Academic Press. San Diego

[23] Dix NJ dan Webster J. 1995. Fungal ecology. Chapman \& Hall. London

[24] Sutarman, Hadi S, Achmad, Suryani, A \& Saefuddin A. 2004. Sumber inokulum patogen hawar daun bibit Pinus merkusii di pesemaian. J. Nabatia 1 (2): 267-77

[25] Sulistyowati L, NL Hamidah, \& S. Djauhari. 1999. Pengaruh jenis dan masa peram ekstrak kompos pada aplikasi Trichoderma spp. untuk pengendalian penyakit bercak daun apel (Marassoninna soronaria). J. Agritek 7 (1): 8-15. 
[26] Harman GE, Howel CR, Viterbo A, Chet I, \& Lorito M. 2004. Trichoderma species-opportunistc, avirulent plant symbionts, Nature Reviews, Microbiol. 2:43-56

[27] Ginting C \& Maryono T. 2011. Efektivitas Trichoderma spp. dengan bahan organic dalam pengendalian penyakit busuk pangkal batang lada. J. HPT Tropika 11:147-156

[28] Howell CR. 2003. Mechanisms employed by Trichoderma species in the biological control of plant diseases: the history and evolution of current concepts. Plant Dis. 87, 4-10

[29] Verma M, Brar SK, Tyagi RD, Surampalli RY, \& Valero JR. 2007. Antagonistic fungi, Trichoderma spp.: panoply of biological control. Biochemistry Engineering Journal 37, 1-20

[30] Benítez T, Rincón AM, Limón MC, \& Codon A. 2004. Biocontrol mechanisms of Trichoderma strains. Int. Microbiol. 7 (4), 249-260

[31] Harman GE. 2006. Overview of mechanisms and uses of Trichoderma spp. Phytopathology 96, 190-194

[32] Vinale F, Sivasithamparam K, Ghisalberti EL, Marra R, Barbetti MJ, Li H, Woo SL, \& Lorito M. 2008. A novel role for Trichoderma secondary metabolites in the interactions with plants. Physiol. Mol. Plant Pathol. $72,80-86$

[33] Gravel V, Antoun H, \& Tweddell RJ. 2007. Growth stimulation and fruit yield improvement of greenhouse tomato plants by inoculation with Pseudomonas putida or Trichoderma atroviride: possible role of indole acetic acid (IAA). Soil Biol. Biochem. 39, 1968-1977

[34] Srivastava R., Khalid A, Singh US, \& Sharma AK. 2010. Evaluation of arbuscular mycorrhizal fungus, fluorescent Pseudomonas and Trichoderma harzianum formulation against Fusarium oxysporum f. sp. lycopersici for the management of tomato wilt. Biological Control 55, 24-31

[35] Vargas Gil S, Pastorb S, \& Marcha GJ. 2009. Quantitative isolation of biocontrol agents Trichoderma spp. Gliocladium spp. and 
Actinomycetes from soil with culture media. Microbiol. Res. 164, 196-205

[36] Sutarman \& Prihartiningrum AE. 2015. Penyakit hawar daun Pinus merkusii di berbagai persemaian kawasan utama hutan pinus Jawa Timur. J. HPT Tropika 15 (1): 44-52

[37] Ginting C. 1997. Screening for fungal biocontrol agents against Phytophthora capsici Leonian ( $P$. Palmivora MF4) causing root rot on black peppr. Hlm, 406-410 dalam Prosiding Kongres dan Seminar Ilmiah Perhimpunan Fitopatologi Indonesia. Kusuma SSH (peny.), 27-28 Oktober 1997. Palembang

[38] Guba EF. 1961. Monograph of Monochaetia and Pestalotia. Harvard Univ. Press. Massachusetts

[39] Achmad, S Hadi, EN Herliyana, \& A Setiawan. 1999.

Patogenisitas Rhizoctonia solani Pada Semai Pinus merkusii dan Acasia mangium. Jurnal Manajemen Hutan Tropika 1 (1-2): 10-17

[40] Sumardiyono C, Wibowo A, \& Suryanti. 2007. Pengendalian penyakit layu pisang dengan Fusarium nonpatogenik dan Fluorescent Pseudomonads. Jurnal Perlindungan Tanaman Indoneia, 13 (2): 142-150

[41] Fadhilah S, Wiyono S \& Surahman, M. 2014. Pengembangan teknik deteksi Fusarium patogen pada umbi benih bawang merah (Allium ascalonicum) di laboratorium. J. Hort. 24(2):171178

[42] Noveriza R, Tombe, Rialdy H, \& Manohara D. 2005. Aplikasi Fusarium oxysporum non patogenik (FoNP) untuk menginduksi ketahanan bibit lada terhadap Phytophthora capsici L. Buletin Penelitian Tanaman Rempah dan Obat, 16 (1): 1-11

[43] Isniah US \& Widodo. 2015. Eksplorasi Fusarium nonpatogen untuk pengendalian penyakit busuk pangkal pada bawang merah. J Fitopatol Indones, 11 (1): $14-22$ 
[44] Dayana Amira R, Roshanida AR, Rosli MI, Zahrah SFMF, Anuar MJ, \& Adha NCM. 2012. Bioconversion of empty fruit bunch (EFB) and palm oil mill effluent (POME) into compost using Trichoderma virens. African Journal of Biotechnology 10, 18775-18780

[45] Yedidiaa I, Benhamoub N, Kapulnikc Y, \& Cheta I. 2000. Induction and accumulation of PR proteins activityduring early stages of root colonizationby the mycoparasite Trichoderma harzianum strain T-203. Plant Physiology and Biochemistry 38 (11): 863-873

[46] Al-Taweil HI, Osman MB, Aidil AH, \& Wan-Yussof WM. 2009. Optimizing of Trichoderma viride cultivation in submerged state fermentation. Am. J. Appl. Sci. 6, 1277-1281

[47] Chowdappa P, Kumar SPM, Lakshmi MJ, \& Upreti KK. 2013. Growth stimulation and induction of systemic resistance in tomato against early and late blight by Bacillus subtilis OTPB1 or Trichoderma harzianum OTPB3. Biol. Control 65, 109-117

[48] Rodriguez HG, Maiti R, \& Kumari CA. 2016. Biodiversity of leaf traits in woody plant species in Northeastern Mexico: A Synthesis. Forest Res 5: 169. doi:10.4172/2168-9776.1000169

[49] AlAskar AA \& Rashad YM. 2010. Arbuscular mycorrhizal fungi: a biocontrol agent against common bean Fusarium root rot disease. Plant Pathol. J. 9, 31-38

[50] Dubey SC, Suresha M, \& Singha B. 2007. Evaluation of Trichoderma species against Fusarium oxysporum f. sp. ciceris for integrated management of chickpea wilt. Biol. Control 40, 118-127

[51] Saravanakumar K, Yu C, Dou K, Wang M, Li Y, \& Chen J. 2016. Synergistic effect of Trichoderma-derived antifungal metabolites and cell wall degrading enzymes on enhanced biocontrol of Fusarium oxysporum f. sp. cucumerinum. Biological Control 94 (2016) 37-46 
[52] Gerbore J, Benhamou N, Vallance J, Le Floch G, Grizard D, Regnault-Roger C, \& Rey P. 2014. Biological control of plant pathogens: advantages and limitations seen through the case study of Pythium oligandrum. Environ. Sci. Pollut. Res. Int. 21, 4847-4860.)

[53] Buysens C, César V, Ferrais F, De Boulois HD, \& Declerck S. 2016. Inoculation of Medicago sativa cover crop with Rhizophagus irregularis and Trichoderma harzianum increases the yield of subsequently-grown potato under low nutrient conditions. Applied Soil Ecology 105,137-143

[54] Hu X, Roberts DP, Xie L, Yu C, Li Y, Qin L, Hu L, Zhang Y, \& Liao X. 2016. Use of formulated Trichoderma sp. Tri-1 in combination with reducedrates of chemical pesticide for control of Sclerotinia sclerotiorium on oilseed rape. Crop Protection 79, 124-127

[55] Youssef SA, Tartoura KA, \& Abdelraouf GA. 2016. Evaluation of Trichoderma harzianum and Serratia proteamaculans effect on disease suppression, stimulation of ROS-scavenging enzymes and improving tomato growth infected by Rhizoctonia solani. Biological Control 100, 79-86

[56] Alguacil MM, Torrecillas E, García-Orenes F, \& Roldán A. 2014. Changes in the composition and diversity of AMF communities mediated by management practices in a Mediterranean soil are related with increases in soil biological activity. Soil Biol. Biochem. 76, 34-44

[57] Van der Heijden MG, Streitwolf-Engel R, Riedl R, Siegrist S, Neudecker A, Ineichen K, Boller $T$, Wiemken A, \& Sanders IR. 2006. The mycorrhizal contribution to plant productivity, plant nutrition and soil structure in experimental grassland. New Phytologist 172, 739-752 
[58] Sutarman. 1997. Effect of compost to intensity of mychorryzal infection on the roots of Pinus merkusii. J. Agritek 5 (2): 79-90

[59] Widyati E., Irianto R.S.B., Santosa S., Najmullah, \& Sutarman. 2001. The impact of carbofuran environmental insecticide against fungi ectomychorryzal Pisolithus arrhizus and Schleroderma columnare inoculated on seedlings of Pinus merkusii Jung et de Vries. J. Agritek 9 (3): 1178-1182

[60] Heinemeyer A, Hartley IP, Evans SP, Carreira De La Fuente JA, \& Ineson P. 2007. Forest soil CO2 flux: uncovering the contribution and environmental responses of ectomycorrhizas. Glob. Change Biol. 13, 1786-1797. doi:http://dx.doi.org/10.1111/ j.1365-2486.2007.01383.x

[61] Barea JM, Palenzuela J, Cornejo P, Sánchez-Castro I, Navarro-Fernández C, Lopéz-García A, Estrada B, Azcón R, Ferrol N. \& Azcón-Aguilar C. 2011. Ecological and functional roles of mycorrhizas in semi-arid ecosystems of Southeast Spain. J. Arid Environ. 75, 1292-1301. 